\title{
コンピュータによる仏教混淆梵語の研究 (1)
}

一仏教混淆梵語写本研究の問題点——

\section{塚本㤵祥}

\section{§1. 仏教梵語文献の特色}

日本に和ける伝統的仏教研究は，漢訳仏典を拠り所としてきた。しかし19世紀 後半にヨーロッパの仏教研究の方法が日本に導入されて, サンスクリット原典や, パーリ聖典，チベット語訳，中央アジアの少数民族語による諸訳が知られるよう になり，同一経典に対するサンスクリット原典と異種の訳本とを比較研究するこ とが可能になった。

サンスクリット原典を第一資料として取り上げ得るようになったことは，従来 の漢訳のみに頼った時代に比べて，文献の本来の語意を正確に把握することを可 能にした。しかしサンスクリットの写本は，伝承の過程に和ける流伝の時代と地 域，書写生の出身地等の影響を受けて，言語の音声学・文法学上の变形，語彙の 挿入・修正，並びに文献構成の改編等が行われている。しかも，ネパール・チベ ット系, カシミール系, 中央アジア系の写本相互の間に著しい相違が認められる。 またチベット語訳は同系の原典からの翻訳とみなされる。

これに対して，漢訳，特に古訳・旧訳の仏典は，現存するサンスクリット写本 よりむ古く, 原典の古形を推定するための多くの痕跡を残している。概して，こ れらの漢訳仏典は中期インド・アリアン語，すなわちプラークリットを混淆した 仏教混淆梵語からの翻訳であるが，新訳（7 世紀以降）の原典となった文献に括 いては，梵語化 (Sanskritization) が著しく進む一方, 語彙の置換・修正がなされ ていることを指摘できる。これらの事情を勘案して，われわれは仏教混淆梵語の 研究のために, 資料が変化に富み, 異種系統の多くの写本が現存する法華経を, 研究対象として取り上げた。

\section{$\S 2$. 既刊校訂本の問題点}

梵文の法華経原典の校訂本は，H. ケルンと南条文雄博士によって初めて出版 された ${ }^{1)}$ このテキストは，ネパール系写本 6 本 (11-12 世紀 3 本 ；18-19 世紀 3 本）及び中央アジア系写本 1 本（7-8 世紀）に準拠し，両系統写本の相違個所を 註記しているが，それはすべてに亘っているとはいえない。しかも校訂者の法華 


$$
\text { コンピュータによる仏教混淆梵語の研究(1)（塚 本） }
$$

経の理解と判断に基ついて，プラークリット形語彙の混淆したテキストをClassical Sanskrit に修正する傾向を示している。ケルン以後に出版された校訂本も 同様の編集方針に基ついている。この傾向は梵文法華経原典のみならず，あらゆ る梵語仏典の校訂本作成に見られる共通の特色である。

梵文法華経写本は出土の地域によって，

1. ネパール・チベット本

2. カシミール (ギルギット) 本

3. 中央アジア本

の 3 種に分類できる。写本の数は端本を含めれば60種にも達し, 書写の年代も 5 一19世紀に亘っている。この事実を考慮するとき，これらの写本を一律に取り扱 らことは，写本の流伝の系統と形態，使用された言語や文字の特殊性を無視する ことになり, 法華绿原典の原形推定に関しても, 種々の問題を派生せしめる。

§3. 写本の比較一新たな問題の提起

従来の校訂本で解決されなかった問題が，写本の比較研究によって解明される 3 例を以下に示そう。

(1) Avalokitasvara/Avolokiteśvara

現世の危難を救済して人々に利益を与学を観音菩薩の信仰は，インドに発生し て，中央アジアから中国を経て日本に伝来し，深く民臬の間に根を下している。 ところが 6 世紀以降の梵語仏典では，すべてが Avalokiteśvara（観自在）と記さ れているのに対して，古訳・旧訳の漢訳仏典では「光世音」「観音」「観世音」と 意訳され，新訳では「観自在」と記されている。これについては長い間疑問がも たれていた。N.D.ミミノフは大谷探検隊によって蒐集された中央アジア出土の 梵文法華経断簡 ${ }^{2}$ ( 5 世紀末) に，Avalokitasvara（観音）の語が 5 回現われるこ とを指摘し，観音の原語と漢訳との関係を推定した。

1. 中央アジア出土の梵語写本はこの菩薩名の古形として Avalokitasvara を 与觉る。

2. これは通俗的漢訳形「観音」に対比する。

3. A. D. 600年までの中央アジア・中国・インド出身の漢訳者は音 (svara)の 要素を含む語形「観世音」(Avalokitalokasvara) を用いる。

4. 他に「観世自在」(Avalokita-lokeśvara) 「観世音自在」(Avlokita-lokasvareśvara）が使用された。これは, 菩薩の二つの名称 Avalokitasvara と Lokeśvara の混淆によって表現された。 
5. 7 世紀に Avalokitasvara-lokeśvara の省略形 Avalokiteśvara が古い形 態に取って代り，それが中央アジアに流入し，インドやチベットにはそれの みが存続した。

6. 玄牀はこの原語をインドから将来し，これを唯一の正形とみなして「観自 在」と訳した。それは文献に採用されたが，中国や日本では古い形態が依然 として流行した。

本田義英博士 ${ }^{3)}$ はミロノフの説を一応認めながらも，玄応の『一切経音義』に 雪山伝来の経本に śs の転誂が認められるとする説に着目し, 法華経普門品の偈 に meghasvara dundubhisvara(雲音鼓音) といら句が，ある異本で meghaśvara dundubhiśvara とあって, śs/s の混用例があることを論拠として, Avalokitasvara が*Avalokitaśvara と誤写され，ヒンドゥー教の最高神 İśvara（自在神）の影 響を受けて，プラークリットの連声法から avalokita+İ́sara＞*Avalokita'śvara (観自在)となったことを推定し，これを梵語の連声法に修正して，avalokita + iśsvara>Avalokiteśvara の語形を生ずるに至った，との仮説を提示している。

要するに，5世紀初頭の『妙法連華経』では，「この観世音菩薩を聞いて一心 に名を称えれば，観世音菩薩は即時にその音声を観じて，皆解脱することを得せ しめん」(大正 $9 ， 56 \mathrm{c}$ ) と宣言している。そして菩薩は人々を救済するために三十 三身を現ずる。これは人々に対する仏陀の慈悲の顕現である。大乗仏教の成立と ほぼ同じ頃，ヒンドゥー教では最高神 (İśvara 自在神) ヴイシュスが人々に対す る神の恩寵として権化するという信仰があった。6ー7 世紀に仏教はヒンドゥ一 教の著しい影響を受けるようになったとき，上記諸説のような経緯で, Avalokitasvara>Avalokiteśvara の修正がなされたものと推定される。

(2) Amitāyus/Amitābha

『無量寿経』や『阿弥陀経』によって知られる浄土経典には，阿弥陀仏とその 浄土の信仰が説かれている。この経典は, 法華経とほぼ同じ $1-2$ 世紀に西北イ ンドで成立したものと推定される。

藤田宏達博士の研究4)によれば，梵語仏典には阿弥陀仏を表わす原語として， Amitāyus (<amita +āyus 無量寿) と Amitābha (amita+ābha 無量光) との二 つの梵語名が知られる。しかし，漢訳仏典の音訳では「阿弥陀」のみが伝えられ， 意訳では「無量寿」と「無量光」が「区別されている。そして『無量寿経』の原 典 Larger Sukhāvatīvyūha には Amitābha が主として登場し, Amitāyus が付 随的に記されている。これに対して『阿弥陀経』の原典 Smaller Sukhãvatĩvy. 


$$
\text { コンピュータによる仏教混淆梵語の研究(1)（塚 本） }
$$

ūha では逆の立場であるといら。このことから博士は, 無量寿と無量光との二つ の信仰形態を浄土経典が統一したことを推定している。

法華経では阿弥陀仏と極楽世界について 3 個所で言及される。ケルン本によれ ば，化城喻品と薬王菩薩本事品では Amitāyus となっているが，後期の插入で ある観世音菩薩普門品の偈 (阿弥陀仏讃頌) では, Amitābha が現われる。藤田 搏士はこれを論拠として, 法華経は本来「無量寿」の系統に属したが, 後に「無 量光」に修正された：との説を提示している。

さて梵文法華経写本に現われる阿弥陀仏の梵語名は別表「梵文法華経にみられ る Amitāyus>Amitābha の変化」5) の如くである。これに拉いて 6-8 世紀の カシーミール系及び中央アジア系の写本はすべて Amitāyus となっているが, 11-12世紀のネパール・チベット系写本には, Amitābha への修正が化城喻品と 普門品偈の一部の写本に認められる。しかし17一19世紀の写本では, いずれの個 所でもその修正の傾向が顕著となっている。

普門品偈は『正法華経』（286）及び『妙法連華経』（406）の原訳には含まれな い。ミロノフ転写の大谷本に偈の部分が含まれないのは偈插入以前の痕跡とみな される。現行『妙法連華経』及び『添品妙法蓮華経』に認められる重頌は, 崛多 (Dharmagupta) によって訳 (561) され, 後に插入されたものとみられている。 漢訳の重頌は梵語原典の 1 -26偈に相当する。一方 6-7 世紀には梵語原典では, 阿弥陀仏の讃頌（27一-33偈）が插入されたが，これは漢訳されることはなかった。 その讃頌の中に (Kern's ed. p. 455, ll.5-6),

so caiva Amitābhanāyakah padmagarbhe viraje manorame/

siṃhāsani saṃniṣaṇnako śālarājo va yathā virājate//32//

そして,かの無量光 (カシミール本・中央アジア本 : 無量壽) 導師も, 無垢なる美しい 蓮華のらてなの中の師子座に座って, シャーラ王のように輝いている。 と述べている。この「シャーラ王」とはシャーラ村のヴィシュヌ神のことである が，ケルンの校訂本にネパール本の Amitābhaを採用していることは, 法華経が 本来 Amitāyus の系統に属すると見る見解と矛盾することになる。浄土経典に おける Amitāus と Amitābha の同一視が浄土信仰の主流となり，さらにヒンド ウー教の仏教への影響が顕著となったとき「シャーラ王のように輝く」といら 表現が採用され，さらに11世紀以降に，ネパールに打ける仏教とヒンドゥ一教の 交流を通じて，ヒンドゥ一教の最高神ヴィシュヌに Amitābha が結びつけられ て, Amitāyus を Amitābha に修正することがネパール本の一部でなされたも 


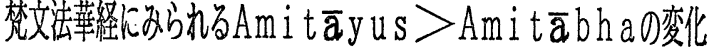

\begin{tabular}{|c|c|c|c|c|}
\hline <写本 > & <筆写年代> & \multirow{2}{*}{$\mid$} & \multirow{2}{*}{$\frac{(\text { 薬王菩薩本事品 XXII-196) }}{-}$} & \multirow{2}{*}{\begin{tabular}{|l} 
(镮世音菩薩普門品XXIV-159) \\
\hdashline-
\end{tabular}} \\
\hline M （㦵知系） & 5 世出 & & & \\
\hline F （挖乃游系） & 6 & - & - & - \\
\hline D1（汃一䒺） & $6-7$ & Amitāyus & Amitāyus & - \\
\hline D2（汃一䐆） & $6-7$ & - & - & Amitāyu nāyako \\
\hline D3（汃一係） & $6-7$ & - & - & - \\
\hline O（中央了㳔系） & $7-8$ & Amitāyus & $\operatorname{Ami}[\quad]$ & [ ] tāyu nāyako \\
\hline K （祚一䊝） & 11 & Amitāyus & Amitāyus & Amitāyu nāyakah \\
\hline Pk（祒䋆） & 11 & Amitāyus & Amitāyus & lokanāyako \\
\hline C 3 (视-䐆) & 11 & Amitāyus & - & - \\
\hline C4（补-䐆） & 11 & Amitāyus & Amitāyus & Amitābhu nāyako ${ }^{+}$ \\
\hline C 5 (视-䋆) & 11 & Amitāyus & Amitāyus & lokanāyako \\
\hline C6（祃-䋆） & 11 & Amitābha* & Amitāyus & Amitāabha nāyako* \\
\hline T2（补-孫） & 11 & Amitāyus & Amitāyus & - \\
\hline T6（补-孫） & 11 & Amitāabha* & Amitāyus & - \\
\hline T 7 (视-孫) & 11 & Amitābha* & - & - \\
\hline N2（视一孫） & (1 1 ) & Amitābha* & Amitāyus & lokanāyako \\
\hline N3（视-䐆） & $\left(\begin{array}{ll}1 & 1\end{array}\right)$ & - & - & - \\
\hline B （补-N系） & $11 / 12$ & Amit $\bar{a} b h a^{*}$ & Amitāyus & lokanāyako \\
\hline N1（禟䐆） & $(11 / 12)$ & Amitāyus & Amitāyus & Amitāyu nāyako \\
\hline A 1 (祃一孫) & $17 / 18$ & Amit $\bar{a} b h a^{*}$ & Amitāahha* & lokanāyako \\
\hline A 2（补係） & $17 / 18$ & Amitābha* & Ámitābha* & Amitābha nāyako* \\
\hline $\mathrm{R}$ （补-孫） & 18 & Amit $\overline{\bar{d}} b h a^{*}$ & Amit $\bar{a} b h a^{*}$ & Amitābha n̄̄ayako* \\
\hline T 8（祄-䋆） & $(18)$ & Amitābha* & Amitāyus & lokanāyako \\
\hline T4（祄一孫） & $18 末$ & Amitz̄abha* & Amit $\bar{a} b h a^{*}$ & Amitābha nāyakah" \\
\hline P 3（祚睬） & 19 & Amit $\bar{a} b h a^{*}$ & Amitāyus & Amitābha nāyako* \\
\hline P1（䃿㐿） & 19 & Amitābha* & Amitāanha* & Amitābha nāyako* \\
\hline P 2（䃿釉） & 19 & Amit $\bar{a} b h a^{*}$ & Amitāyus & Amitāabha nāyako* \\
\hline A 3（祚一䋆） & 19 & Amit $\bar{a} b h a^{*}$ & Amit $\bar{a} b h a^{*}$ & Amitāăbha nāyako* \\
\hline C 1（社-䋆） & 19 末 & Amit $\bar{a} b h a^{*}$ & Amitāyus & Amitāyu nāyako \\
\hline C 2（祢鲧） & 19 末 & Amitābha* & Amitāyus & Ami tāyu nāyako \\
\hline T3（祝一眎） & 19 末 & Amitābha* & Amit $\bar{a} b h a^{*}$ & Amitābha nāyako \\
\hline T9（祃-係） & 19 末 & Amitābha* & Amitābha* & 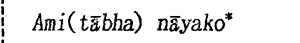 \\
\hline T5（补-鲧） & (19末) & Amit $\bar{z} b h a^{*}$ & Amitāyus & Amitābha nāyako* \\
\hline $\mathrm{Kn}$ （敬硬本） & $1908-12$ & Amitāyus & Amitāyus & Amitābha nāyako* \\
\hline
\end{tabular}

( ) =踪定代 


$$
\text { コソピュータによる仏教混淆梵語の研究(1)（塚 本） }
$$

のと推定すれば，前述の藤田博士の学説は一段と強化されることになる。

(3) 陀羅尼呪に見られる梵語化

法華経陀羅尼品には，法華経を受持し，読誦し，書写し，説法する法師を守護 するための 5 種の陀羅尼呪を述べている。また普賢菩薩勧発品では，法華経を受 持し，読誦し，書写する者に対して，非人の破壊を免かれ，女人の惑乱を避ける ための陀羅尼呪を与えている。

陀羅尼呪は秘密性が要求されたために，語形にプラークリットの特色を保存し ているが，ネパール系写本や密教系儀軌のように年代が降るものの中には，梵語 化の進んだものも指摘される。主な例を次に示そう。な和漢訳仏典の音写は B.力 ールグレン ${ }^{6)}$ と藤堂明保博士 ${ }^{7)}$ の研究による上古音と中古音に基づき，プラーク

リット語形の推定は R. ピッシェル ${ }^{8)}$ と F.エジャートンン゙)拠った。
(正) 正法華経
D sDe-dge Ed.
C Chone Ed.
过 妙法蓮華経
$P$ Peking Ed.
L Lhasa Ed.
送 添品妙法蓮華経 N sNar-than Ed.

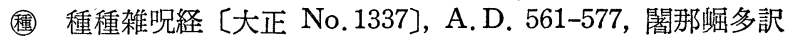
(因) 一切経音義 [大日本校訂縮刻大蔵経, No. 1877], 唐, 玄応撰
透 成就妙法蓮華経王瑜伽観智儀軌 [大正 No. 1000], A. D. 746-774, 不空訳

(1) [Kern's ed. : ălokabhaṣe pratyavekșaṇi] 薬王菩薩説陀羅尼呪 観察光耀䀧

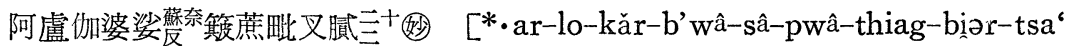
àr-nïed] $=*$ ālokabhasapaccave $(c)$ chane

ālokabhāṣa pratyavekṣane : M

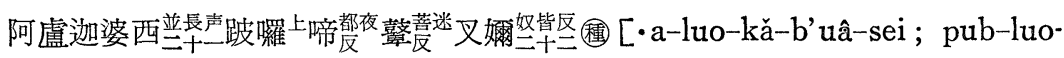
tiei-pie-țș‘ă-ṇii] = *alokabhāse pratyape $(c)$ chaṇi

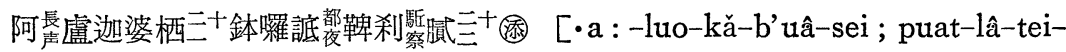

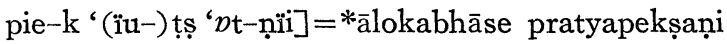

ālokabhāsi apratyavekșaṇi : D1

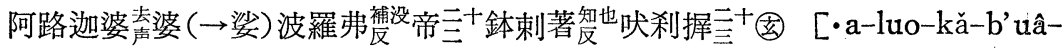
sa-puâ-lâ-pïuət-tiei ; puat-lâ-țiak-b’ înwpi-ț̣ 'ie-ṇii] = *ālokabhāsaprāpte pratyave $(c)$ chaṇi

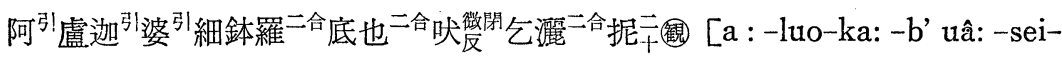
p(uat-) lâ-t(ei-)iai-b' iwpi-k' (iət-) șai-ṇïi] = *ālokābhāse pratyavekșaṇi 
ālokabhāse : K B T6 A1 N2 N3 D2

D P N C L

ālokabhăṣe : C1 C2 C4 R P1 P2 T3

T4 T5 T9 A3 N1

ālokāvabhāṣe : C5 C6 pratyavekșanī: K N C L

prattyavekșanīi : $\mathrm{P}$

pratyavakșani : $\mathrm{C} 1 \mathrm{C}_{2} \mathrm{C} 4 \mathrm{C} 5$

C6 B P1 P2 T3 T4 T5

T6 T8 T9 A1 A3 N1

N2 N3 D2

（2） [Kern's ed. : abhyantarapār:śuddhi mutkule] 薬王菩薩説陀羅尼呪 究竟清浄無有抗坎正

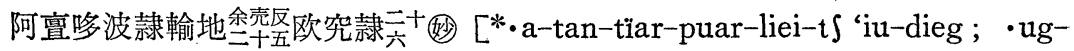
kiog-liei] $=*$ attantaparisuddhi ukkule

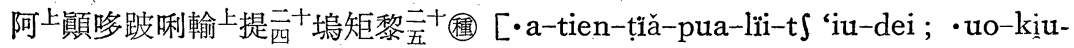

-liei] $=*$ atyantaparisuddhi ukkule/utkule

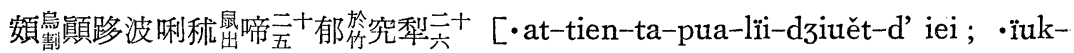

kïəu-liei $]=*$ atyantapariśsuddhi u $k k u l e$

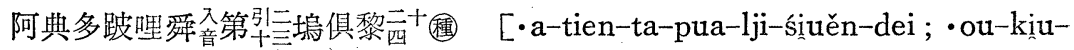

liei] =*atyantaparisuddhi utkule

atyantapāriśuddhi : $\mathrm{N}$

atyantarapăriśuddhi : $\mathrm{K} \mathrm{R} \mathrm{D}$

atyantarabheriśuddhi : $\mathrm{C}$

atyantarabheriśuddhi-m-utkulo: $\mathrm{P}$ utkulo: $\mathrm{P}$

udkulo: C

ukule : R P1 P2 T4 T5 T9 A3 N1 N2

ukkule: T6 T8 N3 D1 D2

utkule : $\mathrm{C} 1 \mathrm{C} 2 \mathrm{C} 4 \mathrm{C} 5 \mathrm{C} 6 \mathrm{~N} \mathrm{~L}$

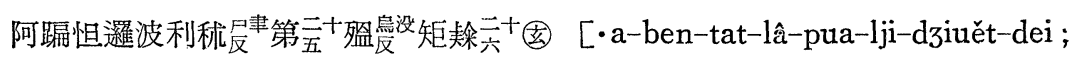

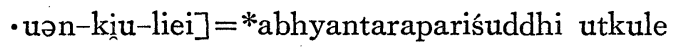

abhyantarapăriśuddhī: C5 C6 T8 N3 kulo: T3

abhyantaraviśuddhi : C4

udkulo : A1

anyantapāriśuddhī : D2

kukkula : $\mathrm{K}$

（3） [Kern's ed. : dharmaparīkșite] 薬王萻薩説陀羅尼呪 而察於法(1)

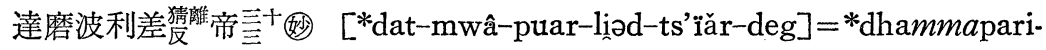
cchide

達磨波利差低言因 $\quad$ [dat-muâ-pua-lji-ț̣ 'ie-tei] $=*$ dhammaparicchite 達磨鉢離器绹严十圈 [dat-muâ-puat-ljie- $\left.\mathrm{k}^{\prime} \mathrm{ji}-\mathrm{tiei}\right]=*$ dhammaparikhite 


$$
\text { コンピュータによる仏教混淆梵語の研究(1)（塚・本） }
$$

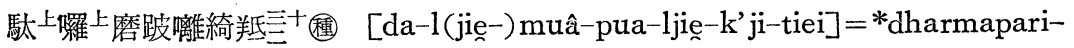
khite

達磨跛哩乞史合帝三十観 $\quad[$ dat-muâ-pua-lji-k '(iət-șiei-tiei $]=* d h a m m a p a-$ rikșite

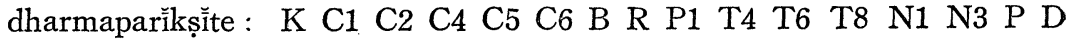
N C L

dharmmaparikṣite : P2 T3 T9 A1 A3

以上梵語写本と漢訳・チベット語訳の音写とを比較をすることによって明かな ように，陀羅尼呪のシラブルの中にサンスクリットのそれに対比されるプラーク リット形を指摘できる。すなわち，(1) pacca=pratya (BHSG 2.18); ccha=kșa (Pischel 320, 321) (2) $\mathrm{tta}=\mathrm{tya}($ Pischel 281); $\mathrm{kku}=\mathrm{tku}$ (3) $\mathrm{mma}=\mathrm{rma}$; cchi $=\mathrm{kṣi} ; \mathrm{de}=\mathrm{te} ; \mathrm{khi}=\mathrm{kṣi}$ (Pischel 317，319）がそれであって，時間の経過の中で プラークリットの語形語彙が梵語化したことを認め得る。

かようにして, 梵語仏典の原形推定の探求と並行して, 写本変遷の過程を検討 することが不可欠の要件となってくる。よってこれに客観的な資料を提示するた めに，写本のデータベース化が必要となる。われわれの出版『梵文法華経写本集 成一ローマ字本・索引』全14巻は，この目的のために企画された。

1) H. Kern \& B. Nanjio: Saddharmapuṇdarīka, Bibliotheca Buddhica X, St. Petersbourg 1908-12.

2) N. D. Mironov : Buddhist Miscellanea, JRAS 1927, pp. 249-252; N. Dutt : Saddharmapundarika, with N.D.Mironov's Reading from Central Asian MSS., Bibliotheca Indica, Calctta 1953.

3）本田義英『仏典の内相と外相』, pp.211-260.

4) 藤田宏達『原始浄土思想の研究』, pp.259-335.

5) 『梵文法華経写本集成』(Sanskrit Manuscripts of Saddhrmapundarika, Collected from Nepal, Kashmir and Central Asia) 中村瑞隆・塚本啓祥・田賀龍彦・

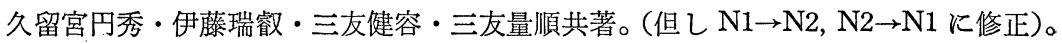

6) B. Karlgren : Grammata Serica Recensa, Stockholm 1972.

7) 藤堂明保『漢字語源辞典』。

8) R. Pischel : Grammatik der Prakrit-Sprachen, Strassburg 1900.

9) F. Edgerton: Buddhist Hybrid Sanskrit Grammar and Dictionary, New Haven 1953.

〈キーワード〉 仏教混淆梵語, 法華経写本, コンピュータ処理 